\title{
IJIR: Your Sexual Medicine Journal - Past, Present and Future
}

\author{
Ege Can Serefoglu $\mathbb{D}^{1}$
}

Received: 13 June 2019 / Accepted: 13 June 2019 / Published online: 24 June 2019

C) Springer Nature Limited 2019

Sexual Medicine is one of the most rapidly evolving fields of medicine in the new millennium. The discovery of the first oral therapy for the treatment of erectile dysfunction illuminated the dark rooms of long-neglected (but ever present) sexual problems. The journal that you are reading was founded in 1988, a decade before the launch of Viagra, and has served as the flagship journal of the sexual medicine world ever since by continuing to inform its readers about the most important developments of this challenging field.

This year, we are celebrating the 30th anniversary of the International Journal of Impotence Research (IJIR) and I am honored to inform you that I have recently become Editor-in-Chief of this prestigious journal. In maintaining the preeminent standing and quality of IJIR, especially in the days of constant changes in the dynamics of academic publishing, I am thankfully not alone. As with every scientific journal, IJIR has always relied on its readers, authors, reviewers, and editors, and I rely on all of you too. As such, IJIR is also your journal and we have emphasized this by adding "Your Sexual Medicine Journal" to its name.
Whenever you have time, please explore our bi-monthly content and enjoy the free collections that we provide for our readers on our website. If you have a paper to submit, please consider IJIR: Your Sexual Medicine Journal. Once you receive an invitation to review a manuscript for us, please think twice before you reject it as we value your expert opinion greatly. Please review our dynamic editorial board members and do not hesitate to get in touch with any that you know. If you believe that we need to add expertize to our editorial board, please do not hesitate to let us know. Please also visit our social media platforms on Twitter, Facebook, Instagram, and LinkedIn so that we can continue to increase engagement with our readership and the community.

We have highlighted important developments in sexual medicine for the past 30 years, and are here with you on your quest to learn about the recent advances in sexual medicine now and into the future. Our future will be even brighter with your continued support.
Ege Can Serefoglu

egecanserefoglu@hotmail.com

1 Bahceci Health Group, Urology, Istanbul, Turkey 